\author{
АНТОН ДЁМИН \\ 0000-0002-1459-7819 \\ Институт русской литературы \\ (Пушкинский Дом) \\ Российской Академии наук \\ Отдел русской литературы XVIII века \\ 199034 Санкт-Петербург \\ наб. Макарова, д. 4 \\ anton_demin@mail.ru
}

\title{
«ПОДЛОЕ ЗВАНИЕ ТЕАТРАЛЬНОГО \\ СТИХОТВОРЦА»: А. П. СУМАРОКОВ \\ И ДЖ. БОНЕКИ
}

\section{"THE DESPICABLE RANK OF A THEATRICAL VERSIFIER": ALEXANDER SUMAROKOV AND GIUSEPPE BONECHI}

Рассмотрено упоминание Дж. Бонеки в письме А. П. Сумарокова от 12 марта 1761 г. к И. И. Шувалову в контексте ссоры с К. Е. Сиверсом и отставки Сумарокова от театра и от службы. Выражение «подлое звание театрального стихотворца» толкуется в свете социального положения Бонеки как подчиненного в придворной итальянской труппе, тогда как Сумароков претендует на руководящую должность в русской. Рассмотрены творческие связи Сумарокова и Бонеки в свете конкуренции русской и итальянской трупп при дворе. Отставка Бонеки в 1752 г. была для него менее болезненна, чем отставка для Сумарокова в 1761 г., поскольку он легко мог найти себе место как театральный деятель при любом европейском дворе, а Сумароков, создававший уникальный русский театр, был более уязвим в своем социальном положении.

Ключевые слова: Александр Сумароков, Джузеппе Бонеки (Бонекки), русский театр, опера, социальное положение писателя.

The paper examines the mention of Giuseppe Bonechi made by Alexander Sumarokov in his letter to count Shuvalov dated the $12^{\text {th }}$ March 1761 in the context of the quarrel with count Sievers and of Sumarokov's dismissal from theatre and from service. The expression "the despicable rank of a theatrical versifier" is interpreted in the light of Bonechi's social position as a subordinate in the court's Italian troupe, while Sumarokov aspires to a leading position in the Russian company. The artistic relationship of Sumarokov and Bonechi is examined from the point of view of the competition between the Italian and the Russian company at the court. Bonechi's dismissal in 1752 
was less painful than that of Sumarokov in 1761 because the Italian could easily find a place at any European court as a man of theatre, while Sumarokov, having created the unique Russian national theatre, was considerably more vulnerable due to his social position.

Keywords: Alexander Sumarokov, Giuseppe Bonechi (Bonecchi), Russian theatre, opera, writer's social position.

Русская литература XVIII века во многом определяет структуру, а также социальный статус художественной словесности и ее создателей в российском обществе на последующие два столетия и дальше (это покажет время). Она являет нам ряд точек отсчета в развитии, зарождении или, что не менее важно, отсутствии зарождения тех или иных явлений литературного процесса, поясняющих его позднейшие особенности. Многие из этих точек отсчета, в частности, зарождение русскоязычного музыкального театра, помогает увидеть внимательное изучение литературного пути А. П. Сумарокова, которым последние годы специально занимаются сотрудники Отдела русской литературы XVIII в. Института русской литературы (Пушкинский Дом) Российской академии наук в ходе подготовки к изданию полного комментированного издания его сочинений.

Предлагаемая статья содержит материалы для историко-литературного комментария к высказыванию Сумарокова, приведенному в заголовке: «Подлое звание театрального стихотворца» применительно к Дж. Бонеки ${ }^{1}$. Мы встречаем его в письме к И. И. Шувалову от 12 марта $1761^{2}$. Это письмо было написано в самый разгар ссоры Сумарокова с графом К. Е. Сиверсом, возглавлявшим Придворную контору. С начала 1759 г. в ее подчинение входила созданная в 1756 г. русская придворная труппа ${ }^{3}$. А к концу этого года Сумароков уже аттестовал Сиверса в «Трудолюбивой пчеле» клопом на «прекрасном теле Мельпомены», «блохой чухонской» и призывал «чад любезного моего отечества освободить Российский Парнас от сея гадины». Сиверс не остался в долгу, и уже в начале 1761 г. Сумароков писал отчаянные письма к Шувалову, умоляя и требуя сохранить ему директорскую должность при Российском театре. В марте, по-видимому, драматургу было предложено оставить руководство, передав его Ф. Г. Волкову или

${ }^{1}$ В русской литературе, связанной с данным материалом, часто встречается форма этого имени Бонекки, однако источники XVIII в., русские и зарубежные, а также справочники, чаще приводят форму Бонеки (Bonechi), поэтому мы придерживаемся eе.

${ }^{2}$ См.: Письма русских писателей ХVIII века, Ленинград 1980, с. 90-91; Комментарий В. П. Степанова, с. 194.

${ }^{3}$ Первоначально русская труппа была создана как вольная и коммерческая, но дела ее не пошли, поэтому руководивший ею Сумароков добился ее передачи в ведение Придворной конторы. 
И. А. Дмитревскому, но продолжать обеспечивать театр репертуаром, сочиняя новые пьесы. Именно это предложение вызывает его особенное возмущение. Он трижды повторяет в письме: «я определен именным указом в директоры театра, а не в подлое звание театрального стихотворца, каков был Бонеки»; «И определен я не Бонекием к театру, но директором»; и в последней строке: «а театральным поэтом Бонекием из директоров театра я не буду, хотя бы мне это живота стоило». Как известно, дело завершилось отставкой Сумарокова от театра и от службы и тяжелейшим творческим кризисом длиною в семь лет, в течение которых Сумароков более не писал для театра.

Издавая письма Сумарокова в 1980 г. В. П. Степанов привел краткие биографические сведения о Дж. Бонеки. Либреттист прибыл в Россию в 1742 г., с новой итальянской труппой, был определен сочинителем опер с жалованием 600 рублей, написал несколько либретто для придворного композитора Франческо Арайя, испросил отставку и в 1752 г. отбыл в родную Флоренцию, получив пенсион от российского двора. Скончался после 1795 г. Говоря о подлом звании театрального стихотворца, Сумароков мог иметь в виду как заказной характер творчества Бонеки, так и его низкое происхождение из семьи мебельщика или, как уточняют некоторые биографии, мастера по росписи деревянных ларей.

Приведенных сведений, наверное, было бы достаточно для ближайшего комментария, однако в свете новейших исследований творчества Сумарокова эти факты обретают бо̀льшую смысловую объемность и могут подтолкнуть к более внимательному изучению творческой биографии Бонеки, Сумарокова и их взаимоотношений. Действительно, почему же заезжий флорентинец так крепко засел в уме видного русского драматурга, что тот вспомнил о нем в 1761 г., когда Бонеки уже почти десять лет не было в Петербурге? Вестей от него тоже не было, поскольку он не стал соблюдать условия пенсиона при отставке и не высылал в Россию по два оперных либретто в год, как было условлено 4 .

Сведения о ранней биографии Бонеки и о его русском периоде действительно весьма скудны ${ }^{5}$. Сын мелкого ремесленника, он, благодаря

\footnotetext{
4 Это неудивительно: условием контракта была выплата всего двухсот рублей в год. По сравнению с жалованием даже простых музыкантов при русском дворе это была незавидная сумма.

${ }^{5}$ Их можно почерпнуть из словаря итальянских биографий Треккани: Bocnechi Giuseppe, [в:] Dizionario biografico degli italiani, Roma 1969, т. 11, с. 741-743; на русском языке: Ст. Гардзонио, Бонекки (Вопессhі или Вопесhі) Джузеппе, [в:] Музыкальный Петербург. Энциклопедический словарь, Санкт-Петербург 2000, т. 1: XVIII век, кн. 1: А-И, с. 144-146. Более ранние русские биографические справки о Бонеки в Энциклопедическом словаре Брокгауза и Эфрона и в Русском биографическом словаре бедны сведениями и пестрят фактическими ошибками.
} 
богачу Уголино Грифони, окончил факультет права Пизанского университета, вернулся во Флоренцию для занятий литературой, а дальше в его биографиях упоминается вполне авантюрный и даже анекдотический эпизод, приведший его в Россию. Молодой литератор якобы стал жертвой известного флорентийского мошенника, армянина по имени Григорий Абдулла (Gregorio Addollo), который обещаниями прибыльных должностей заманил его в Польшу, там обобрал и бросил без средств к существованию в Гданьске. Там его случайно встретила и взяла с собой группа итальянских музыкантов, отправлявшаяся под руководством Ф. Арайя к русскому двору, где Бонеки получит жалование в половину суммы, причитавшейся руководителю итальянской труппы, казенную квартиру и пропитание 6 . Его творческая деятельность в России началась в 1744 г. сочинением либретто для оперы Арайя Селевк, поставленной в Москве по случаю годовщины коронации и подписания Абоского мирного договора, завершившего русско-шведскую войну ${ }^{7}$. К этому времени относится, вероятнее всего, первая встреча Бонеки и Сумарокова на творческом поприще. К упомянутой постановке был анонимно издан сокращенный русский перевод либретто, а также итальянская и французская версии, согласно тогдашнему обыкновению8. Ознакомительные переложения итальянских комедийных сценариев, а затем оперных либретто на русский язык выполняли академические переводчики: В. К. Тредиаковский, И. Горлицкий, П. Медведев, А. В. Олсуфьев. Переводы либретто иногда были хотя бы частично стихотворными, но это были неуклюжие силлабические вирши с обилием церковнославянских слов и оборотов. Перевод Селевка привлек внимание И. З. Сермана', который отметил необычную для того времени качественную силлабо-тоническую версификацию в переводе

\footnotetext{
${ }^{6}$ Фундаментальное документальное исследование Театральная жизнь России в эпоху Елизаветы Петровныл. Документальная хроника, сост. Л. М. Старикова, Москва 2003, 2005, 2011 содержит множество подробностей, связанных с материальным благополучием Бонеки, печатанием его либретто, часто небрежно или не ко времени переводимых, что лишний раз свидетельствует о его незавидном положении при дворе.

${ }^{7}$ Петербургский музыковед 3. М. Ахметшина подробно рассмотрела рукописные нотные и печатные материалы, оставшиеся от этой оперы, и, в частности, установила, что либретто ее является оригинальным. См.: 3. Ахметшина, «Селевк» $\Phi$. Арайи и ее рукописи в библиотеке Санкт-Петербургской консерватории, «Opera musicologica» 2014, № 3, с. 38-62; Ранее, с легкой руки Р.-А. Моозера считалось, что либретто является плагиатом одноименной музыкальной драмы А. Дзено. См.: R.-A. Mooser, Annales de la musique et des musiciens en Russie au XVIII siècle, т. 1: Des origines à la mort de Pierre III (1762), [Génève 1948], c. 215.

${ }^{8}$ Иногда печаталась также немецкая версия. 3. М. Ахметшина в своей статье не учла итальянскую и французскую версии 1744 г., которые также были тогда опубликованы. Они зафиксированы в издании: Сводный каталог книг на иностранных языках, изданных в России в XVIII веке, Ленинград 1984, т. 1: A-G, с. 141-142, № 466, № 468.

${ }^{9}$ См.: И. 3. Серман, Ломоносов и придворные итальянские стихотвориьы 1740-х годов, [в:] Международные связи русской литературыл. Сб. статей, Москва-Ленинград 1963, с. 112-134.
} 
арий (речитативы были пересказаны прозой). В большинстве случаев при переводе был использован шестистопный ямб с парной рифмовкой и чередованием мужских и женских клаузул, ставший впоследствии главным метром русской драматургии, дидактической и эпической поэзии. К 1744 г. русской силлабо-тонической системой стихосложения на таком уровне могли владеть разве что В. К. Тредиаковский и М. В. Ломоносов, находившиеся в Петербурге, и Сумароков, состоявший в свите А. Г. Разумовского и присутствовавший на московских торжествах. Более того, И. З. Серман отметил в переводе ряд фрагментов и формул, обнаруживающихся в первой трагедии Сумарокова Хорев, из чего сделал вывод, что перевод Селевка принадлежит тоже Сумарокову, хотя традиционно он до сих пор приписывается А. В. Олсуфьеву. Олсуфьев, однако, в это время находился в Дрездене и вряд ли мог получить поручение срочно переводить новую оперу ${ }^{10}$. Недавно наблюдения Сермана проверил и дополнил профессор М. Левитт, занимающийся подготовкой музыкально-драматических произведений Сумарокова для полного собрания сочинений. Он показал, что выражения, найденные в переводе Селевка, встречаются не только в Хореве, но и во всех позднейших трагедиях Сумарокова ${ }^{11}$. Как представляется, Сумароков уже чувствовал в себе потенциал драматического поэта, нащупывал словесный материал для воплощения трагедийного замысла, и подвернувшийся перевод Селевка мог стать для него просто предлогом, пусковым механизмом, освободившим копившуюся творческую энергию. Стоит завершить начатый Серманом и Левиттом анализ и выяснить, какие из рассмотренных выражений действительно являются точным переводом стихов Бонеки, а какие привнесены в перевод Сумароковым ${ }^{12}$. И кажется, что эта творческая встреча стала отправной точкой череды значимых событий в истории русского драматического и музыкального театра.

С 1744 по 1747 г. Бонеки оказался единственным действующим светским придворным драматургом в России, на том самом поприще, на которое вскоре вступил Сумароков. Итальянский литератор был признан, осыпан деньгами, пожалован чином, обласкан двором. И он создавал новые драматические

${ }^{10}$ См.: В. П. Степанов, Олсуфьев Адам Васильевич, [в:] Словарь русских писателей XVIII века, Санкт-Петербург 1999, вып. 2 (К-П), с. 383.

${ }^{11}$ Наблюдения М. Левитта были изложены в докладах на семинаре «Итальянская опера в России», организованном государственным университетом Мачераты (Италия) 20 ноября 2017 г. и на X международной конференции Группы по изучению России XVIII в. 6-11 июля 2018 г. в Страсбурге (Франция). Ожидается также его печатная публикация на эту тему в серии Института русской литературы (Пушкинский Дом) Российской академии наук «XVIII век».

${ }^{12}$ К решению этой задачи было бы уместно приступить после опубликования Левиттом его наблюдений. Возможно, исследователь решит ее сам. Представляется, что для полноты анализа необходимо привлечь к рассмотрению французскую версию либретто. 
произведения по случаю важнейших государственных событий: свадьбы наследника престола, очередной годовщины коронации или дня рождения императрицы, Аахенского мира, завершившего Войну за австрийское наследство. Это были его оперы Сципион, Митридат, Прибежище Тишины. Российская придворная французская драматическая труппа, учрежденная в 1742 г., играла привозную драматургию, часто уже слегка устаревшую, хотя и ставшую классической, - трагедии Вольтера десятилетней давности, трагедии Расина и комедии Мольера давности уже почти восьмидесятилетней. До появления Бонеки композитору Арайя приходилось пользоваться несколько устаревшими либретто Метастазио, а теперь у него всегда под рукой был свежий новый текст, наилучшим образом подстроенный под ситуацию. Однако на рубеже 1740-1750 х гг. творческая активность Бонеки затихает, и в сентябре 1752 г. он просит и незамедлительно получает отставку. Нельзя не заметить, что его ретирада совпадает с бурным увлечением двора нарождающимся русским театром. Это - постановки первых трагедий Сумарокова Хорев, Синав и Трувор, Артистона, Семира, указание Ломоносову и Тредиаковскому написать по трагедии и наконец вызов из Ярославля группы молодых купцов под предводительством Ф. Г. Волкова, будущих актеров русской придворной труппы.

Оставшись без верного помощника, Арайя оказался в некотором замешательстве без нового литературного материала, так что ему пришлось несколько раз в 1752-1753 г. ставить Евдоксию Венчанную, последнюю оперу на либретто Бонеки. Он мог бы вернуться в своей работе к испытанным беспроигрышным либретто Метастазио, однако в петербургском воздухе уже витала идея задействовать русских придворных певчих в постановке музыкальной драмы на стихи достигшего вершины признания Сумарокова, которая была осуществлена в 1755 г. оперой Цефал и Прокрис. Это была настоящая победа русского театрального искусства: драматург заставлял композитора осваивать новые музыкально-драматические формы, более свойственные французской лирической трагедии, чем итальянской опере-сериа, диктовал ему каждую стихотворную строчку для верного интонирования. Сумароков был весьма доволен этим опытом, написал похвальные мадригалы в честь Арайя и исполнительницы главной партии Елизаветы Белоградской. Не вполне остался доволен, вероятно, Арайя и итальянская труппа. В январе 1755 г. они представили итальянскую оперу на либретто Метастазио Александр в Индии и деятельность их переместилась к малому двору в Ораниенбауме, где Арайя писал камерные кантаты и возобновлял свои старые работы, в том числе, на либретто Бонеки ${ }^{13}$, в то время как при дворе был официально учрежден российский театр и приглашена

\footnotetext{
${ }^{13}$ В частности, Прибежище Тишины в 1756 г. и Беллерофонт в 1757 г.
} 
новая итальянская труппа под управлением антрепренера Дж. Б. Локателли, привлекшая императрицу сугубо комедийным репертуаром.

В этой обстановке единственной данью высокому жанру в опере оказалась в 1758 г. Альцеста Г. Ф. Раупаха на русское либретто Сумарокова, а затем их совместные героические балеты, посвященные победам русской армии в Семилетней войне и имевшие пространную текстовую часть: Прибежище Добродетели в 1759 г. и Новые лавры в 1760 г.

Музыкально-драматические композиции Сумарокова, экспериментальные, новаторские, переносившие на русскую почву опыт французской «лирической трагедии» и «героического балета» могли стать основой отечественного музыкально-драматического репертуара ${ }^{14}$. Однако этому помешал раздор с Сиверсом, приведший к отстранению поэта от его любимого детища. В конце 1760 г. Раупах вернулся к традиционной форме итальянской оперы-сериа, взяв за литературную основу очередного спектакля старое либретто Метастазио Сирой, цุарь Персии (1726). А уже в 1761 г., одновременно с мучительными переговорами об отставке Сумарокова, в Ораниенбауме, при малом дворе начали готовить возобновление оперы Арайя на либретто Бонеки Селевк, увы, слишком хорошо Сумарокову знакомой. Текст на этот раз был издан на итальянском и на французском языке. Думается, именно этот эпизод живо напомнил строптивому, пылкому, отчаянному литератору-созидателю и первопроходцу образ пронырливого сговорчивого театрального ремесленника-рутинера, каким остался, вероятно, в его памяти Бонеки. Действительно, Бонеки не играл ключевой роли в итальянской придворной труппе. Жалования он получал почти в три раза меньше, чем ее руководитель Арайя, и в два раза меньше скрипачей братьев Даллольо и Д. Мадониса и тем более кастратов П. Мориджи и Л. Салетти, получавших столько же, а иногда и больше, чем Арайя. В его обязанности входило только сочинение текстов для музыкальных представлений. Сумароков же, напротив, создавал придворный русский театр в его целостности: сочинял драмы, разучивал их с актерами, заботился о постановочной части и о престиже труппы в глазах вельможных зрителей. Естественно, что предлагаемое ему звание «театрального стихотворца» должно было казаться ему «подлым» в сравнении с положением директора театра.

Как известно, Сумароков вышел из творческого кризиса и вернулся к редактированию своих ранних трагедий и к созданию новых. На этом пути Сумароков двигался навстречу своему шедевру Димитрию Самозваниу (1771). Он также временами бросал взгляд в сторону продолжавшей царить

\footnotetext{
${ }^{14} \mathrm{~B}$ пользу этого предположения говорит тот факт, что опера Цефал и Прокрис присутствовала в придворном репертуаре почти до конца XVIII в.
} 
при дворе итальянской оперы. Еще, видимо, в 1760 г. он перевел шесть арий из оперы Сирой, над которой тогда работал Раупах. Это вновь был творческий эксперимент: переводы были сделаны с воспроизведением затейливых коротких метров оригинала, в то время в русской поэзии новых и совершенно не освоенных. В 1766 г. он перевел три арии из либретто Метастазио Покинутая Дидона, шедшей тогда в Петербурге с музыкой Б. Галуппи. И, наконец, в 1768 г. прекрасно переложил в русские стихи арию из оперы Ифигения в Тавриде Т. Траэтта на либретто М. Кольтеллини. Все они остались на периферии российского литературного процесса и были впервые изданы только после кончины автора. Мы только недавно узнали, что это были за переводы ${ }^{15}$.

Бонеки устремился навстречу новой карьере. При покровительстве придворного поэта австрийских императоров Метастазио Бонеки получил место придворного поэта при португальском дворе, откуда сбежал после знаменитого Лиссабонского землетрясения. На пути в Лиссабон он поставил несколько своих сочинений в Мадриде с участием знаменитого кастрата К. Броски, более известного под псевдонимом Фаринелли, затем при содействии Метастазио получил дипломатическое назначение от великого герцогства Тосканского в Неаполь. Там он добился признания и покровительства при дворе, способствовал организации театральной жизни, приглашая в легендарный театр Сан-Карло певцов, музыкантов и композиторов. Он создал европейскую славу чешскому композитору Й. Мысливечеку, предложив ему свое «русское» либретто 1750 г. Беллерофонт для новой постановки в 1767 г. в Неаполе. Именно после этой постановки его малозначительная должность легата при флорентийском посольстве в Неаполе сменилась более значимой - консульской. Бонеки шлет подробные отчеты в Тоскану обо всех пересудах неаполитанского двора, собирает сплетни в салонах местной знати и доносит о них при дворе, деятельно, но мелочно интригует и злословит против одних вельмож в пользу других, пресмыкается перед королевой Марией Каролиной, получая обидные прозвища «дипломатического средостения» и «штатного шпиона ее величества». Его презирают и опасаются, а потому везде принимают. Еще в 1790 г. он исполнял свои консульские обязанности. Дата смерти его не установлена, равно как и дата рождения.

Биография Бонеки - история успеха деятельного жизнестойкого, выносливого и не слишком разборчивого в средствах театрального и литературного ремесленника - готовый материал для романтических инвектив против торжествующей посредственности. Однако, учитывая этот личностный фактор, не следует также забывать, что отступление Бонеки перед нарождающимся

${ }^{15}$ См.: А. О. Дёмин, А. П. Сумароков - переводчик итальянских либреттистов П. Метастазио и М. Кольтеллини, «Русская литература» 2018, № 1, с. 52-61. 
русским театром и его побег из Петербурга тем были для него легче и безвреднее, а поражение Сумарокова от Сиверса и отставка от придворного театра - тем тяжелее и болезненнее, что итальянский «театральный стихотворец» был частью уже налаженной системы широкого экспорта во все европейские страны сложившегося художественного явления - придворной итальянской оперы, востребованной везде, везде дававшей пропитание и почет ее устроителям, в то время как «отец русской Мельпомены» творил небывалую, новую, уникальную художественную реальность национального русского театра, который тогда мог быть востребован, оживлен или погублен в единственном месте, - при российском дворе, и который лишь полтора столетия спустя станет образцом для подражания и предметом вывоза в другие страны в форме «Русских сезонов», «системы Станиславского» и советского театрально-кинематографического авангарда.

\section{References}

Akhmetshina, Zarina M. "Selevk" F. Arayi i ee rukopisi v biblioteke Sankt-Peterburgskoi konservatorii. Opera musicologica, No. 3 (2014): 38-62.

Bonechi Giuseppe. In: Dizionario biografico degli italiani. Vol. 11. Roma: Istitituto dell'Enciclopedia italiana, 1969: 741-743.

Demin, Anton O. “A. P. Sumarokov - perevodchik italyanskikh librettistov P. Metastazio i M. Koltellini”. Russkaya literatura, No. 1 (2018): 52-61.

Gardzonio, Stefano. Bonekki (Bonecchi ili Bonechi) Dzhuzeppe. In: Muzykalny Peterburg, Entsikopedicheskii slovar. Vol. 1: XVIII vek. Part. 1: A-I. Sankt-Peterburg: Kompozitor, 2000: 144-146.

Mosser, Robert-Aloys. Annales de la musique et des musiciens en Russie au XVIII siecle. Vol. 1: Des origines à la mort de Pierre III (1762). [Génève], Mont-Blanc [1948].

Pisma russkikh pisatelei XVIII veka. Leningrad: Nauka, 1980.

Serman, Ilya Z. Lomonosov i pridvornye italyanskie stikhotvortsy 1740-kh godov. In: Mezhdunarodnye svyazi russkoi literatury. Sb. statei. Moskva-Leningrad: Nauka, 1963: 112-134.

Stepanov, Vladimir. P. Olsufev Adam Vasilevich. In: Slovar russkikh pisatelei XVIII veka. Part 2 $(K-P)$. Sankt-Peterburg: Nauka, 1999: 383-387.

Svodnyi katalog knig na inostrannykh yazykakh, izdannykh v Rossii v XVIII veke. Vol. 1: $A-G$. Leningrad: Nauka, 1984.

Teatralnaya zhizn Rossii v epokhu Elizavety Petrovny. Dokumentalnaya khronika, ed. Lyudmila M. Starikova. Moskva: Nauka, 2003, 2005, 2011. 